\title{
ADOPTION AND EVALUATION OF A SAMPLE PRETREATMENT PROTOCOL FOR RADIOCARBON DATING OF CREMATED BONES AT HEKAL
}

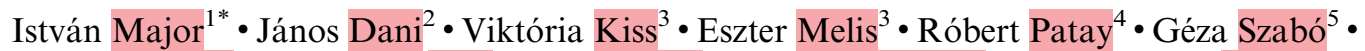 \\ Katalin Hubay ${ }^{1}$ Marianna Túri $^{1}$ István Futó $^{1} \cdot$ Róbert Huszánk $^{6} \bullet$ A J Timothy Jull ${ }^{1,7}$ • \\ Mihály Molnár ${ }^{1}$
}

\author{
${ }^{1}$ Isotope Climatology and Environmental Research Centre (ICER), Institute for Nuclear Research, Hungarian \\ Academy of Sciences (MTA ATOMKI), Bem Square 18/c, H-4026 Debrecen, Hungary. \\ ${ }^{2}$ Déri Museum, Déri Square 1, H-4026 Debrecen, Hungary. \\ ${ }^{3}$ Institute of Archaeology, Research Centre for the Humanities, Hungarian Academy of Sciences, Tóth Kálmán \\ Street 4, H-1097 Budapest, Hungary. \\ ${ }^{4}$ Ferenczy Museum, Main Square 2-5, H-2000 Szentendre, Hungary. \\ ${ }^{5}$ Wosinsky Mór Museum, Szent István Square 26, H-7100 Szekszárd, Hungary. \\ ${ }^{6}$ Laboratory of Ion Beam Physics, Institute for Nuclear Research, Hungarian Academy of Sciences (MTA \\ ATOMKI), Bem Square 18/c, H-4026 Debrecen, Hungary. \\ ${ }^{7}$ Department of Geosciences, University of Arizona AMS Laboratory, 1118 E. Fourth St., Tucson, AZ 85721 USA.
}

\begin{abstract}
A comparative study was undertaken to adopt and evaluate a radiocarbon $\left({ }^{14} \mathrm{C}\right)$ preparation procedure for accelerator mass spectrometry (AMS) measurements of cremated bones at our laboratory, including different types of archaeological samples (cremated bone, bone, charcoal, charred grain). All ${ }^{14} \mathrm{C}$ analyses were performed using the EnvironMICADAS AMS instrument at the Hertelendi Laboratory of Environmental Studies (HEKAL) and the ancillary analyses were also performed at the Institute for Nuclear Research (ATOMKI). After the physical and chemical cleaning of cremated bones, $\mathrm{CO}_{2}$ was extracted by acid hydrolysis followed by sealed-tube graphitization and ${ }^{14} \mathrm{C}$ measurement. The supplementary $\delta^{13} \mathrm{C}$ measurements were also performed on $\mathrm{CO}_{2}$ gas while FTIR was measured on the powder fraction. Based on the FTIR and ${ }^{14} \mathrm{C}$ analyses, our chemical pretreatment protocol was successful in removing contamination from the samples. Good reproducibility was obtained for the $0.2-0.3 \mathrm{~mm}$ fraction of blind-tested cremated samples and a maximum age difference of only $150 \mathrm{yr}$ was found for the remaining case studies. This confirms the reliability of our procedure for ${ }^{14} \mathrm{C}$ dating of cremated bones. However, in one case study, the age difference of $300 \mathrm{yr}$ between two cremated fragments originating from the same urn shows that other processes affecting the cremated samples in the post-burial environment can substantially influence the ${ }^{14} \mathrm{C}$ age, so caution must be exercised.
\end{abstract}

KEYWORDS: cremated bone, FTIR, preparation, radiocarbon dating, stable isotope.

\section{INTRODUCTION}

Since the 1950s, radiocarbon $\left({ }^{14} \mathrm{C}\right)$ dating has played an important role in archaeology. Charcoal, wood, shell, animal or human bones are commonly dated archaeological samples around the world (Taylor and Aitken 1997). Prehistoric intact bones have long been considered as a reliable material for dating, which is generally performed on the organic collagen fraction comprising approximately $20-25 \%$ by weight of dry intact bone (Vaughan 1970; Longin et al. 1971). Unfortunately, where this fraction is not well preserved, ${ }^{14} \mathrm{C}$ ages can be problematic. In the case of cremated remains, collagen perishes during cremation, which was a very common burial practice in various archaeological periods, such as the Bronze Age. In this case, the mineral fraction is the only source of carbon for dating of the bone remains (Hassan et al. 1977; Surovell 2000).

The mineral fraction of bone is mainly composed of calcium phosphate (hydroxyl- or bioapatite), with the general formula $\mathrm{Ca}_{10}\left(\mathrm{PO}_{4}\right)_{6} \mathrm{OH}_{2}$, which is embedded in the fibrous collagen fraction (Mays 1998). The hydroxylapatite crystals incorporate carbonate (0.5-1\% by weight) as a substitute for $\mathrm{PO}_{4}^{3-}$ or $\mathrm{OH}^{-}$ions, hence the ${ }^{14} \mathrm{C}$ dating of this fraction becomes possible (Surovell 2000; Lanting et al. 2001). The structural carbonate originates from blood bicarbonate generated during cell biochemical processes, and is therefore considered to be less prone to

\footnotetext{
*Corresponding author. Email: imajor@atomki.mta.hu.
} 


\section{I Major et al.}

possible reservoir effects than bone collagen (Lee-Thorp and van der Merwe 1991; Richards and Hedges 1999). Although carbon exchange between this structural carbonate and calcitelike contamination in the post-burial environment cannot be entirely excluded but separation of the primary and secondary carbonates is difficult due to the identical chemistry of the contaminant and the phase to be dated. However, it is assumed that during cremation, the heating modifies the resistance and compactness of the bones (Van Strydonck et al. 2005). Based on previous investigations, the physical re-crystallization and chemical changes occurring during cremation make calcined bone less susceptible to inorganic contamination (Lanting et al. 2001). Unfortunately, this re-crystallization of apatite crystals is accompanied by a loss of about one half of carbonate content, making the extraction of the carbon even more difficult. Furthermore, during and after cremation, the carbon isotopic composition of the bioapatite can easily be changed due to different environmental mechanisms, such as dilution by carbon from the fuel itself or ambient atmospheric $\mathrm{CO}_{2}$. Consequently, the carbon isotopic composition of burned (charred) and calcined apatite can be significantly changed by exchange processes with $\mathrm{CO}_{2}$ of the combustion environment which may vary with the duration of the cremation process as well (Zazzo et al. 2009; Van Strydonck et al. 2009, 2010; Hüls et al. 2010).

From a methodological point of view, dating of burned and calcined bones has changed over the past one and a half decades due to the development of small-sample techniques using accelerator mass spectrometry (AMS). The analysis of sample types with extremely low carbon content has become possible using a gas ion source for AMS (as little as $10 \mu \mathrm{g}$ carbon). Numerous studies have already proved that ${ }^{14} \mathrm{C}$ dating of cremated and calcined bones offers reliable ages (Naysmith et al. 2007; Olsen et al. 2008, Starkovich et al. 2013; Quarta et al. 2014). Since there is no available calcined bone standard for comparison, each laboratory generally had to develop unique methods to test their own pretreatment protocols. To test the reproducibility and accuracy of our preparation method, we processed cremated bones of different size fraction and archaeologically associated organic material such as intact bone, charcoal or charred grains and then evaluated the resulting ages. The samples were collected from recently excavated Early and Middle Bronze Age (EBA nad MBA) archaeological sites in Hungary. In addition, Fourier transform infrared spectroscopy (ATR-FTIR) and carbon stable isotope mass spectrometry $\left(\delta^{13} \mathrm{C}\right)$ measurements were also performed to confirm that organic collagen or various other contaminants were not present.

\section{MATERIALS AND METHODS}

At HEKAL, preparation and dating of intact bones and other organic materials has a long tradition, beginning with the measurements using gas proportional counting, and later with the AMS technique (Csongor et al. 1983; Molnár et al. 2013). However, cremated samples were previously excluded due to the small amount of structural carbon $(<1 \mathrm{wt} \%)$ of these samples. This experimental study was our first attempt to prepare cremated bone samples and determine their ${ }^{14} \mathrm{C}$ age. The pretreatment protocol for the cremated bones is principally based on methods published in the last 16 years and currently in widespread use at other ${ }^{14} \mathrm{C}$ dating laboratories (Lanting et al. 2001; Van Strydonck et al. 2005; Olsen et al. 2008). Descriptions of the pretreatment protocols are reasonably detailed in the published work, nevertheless, some preliminary testing and check experiments were required to find the best protocol. Our results are being presented in three subsets: two reproducibility tests (1) and four individual case studies (2) where the cremated samples originating from different Hungarian excavations were compared with associated organic material (Table 1). Furthermore, a dedicated test series (3) was also performed using in parallel the $0.2-0.3 \mathrm{~mm}$ and $0.5-1 \mathrm{~mm}$ fraction of the crushed cremated bones to investigate the possible effect of size fraction on the observed ${ }^{14} \mathrm{C}$ age. 
Table 1 Sample types measured and their codes as a function of the archaeological location.

\begin{tabular}{|c|c|c|c|c|}
\hline Location & Grave & $\begin{array}{l}\text { Charcoal or } \\
\text { grain }(\mathrm{O})\end{array}$ & Bone collagen (B) & $\begin{array}{l}\text { Cremated } \\
\text { bone }(\mathrm{C})\end{array}$ \\
\hline \multirow[t]{2}{*}{ Szigetszentmiklós } & 128 & & & $\overline{\mathrm{SSM} 1-\mathrm{C} / 1-5}$ \\
\hline & 107 & & SSM2-B & $\mathrm{SSM} 2-\mathrm{C} / 1-2$ \\
\hline Debrecen-Szepes & $238 / 319$ & DES-O & DES-B & DES-C \\
\hline Győr-Ménfőscsanak & 6250 & GYM-O & & GYM-C \\
\hline Bonyhád-Biogas F. & 85 & BOB-O & & BOB-C \\
\hline Debrecen, Monostor-e & 563 and 619 & & DEM-B & DEM-C/1-2 \\
\hline
\end{tabular}

\section{Description of the Archaeological Sites}

In the reproducibility test, cremated human bones from the Szigetszentmiklós site (central Hungary) were used. The Szigetszentmiklós, Felső Ürge-hegyi-dúlő site is a remarkable cemetery for the beginning of the EBA period with mixed-ritual types of inhumation, scattered cremation and urn burials. This site was excavated south of Budapest between 2006 and 2007, where a total of 218 Bell Beaker graves were discovered. Grave no. 128 (coded as SSM1-C) was well described by the excavation team (Patay 2013). Grave no. 107 is an unburned inhumation grave of an archer, containing a scattered cremation burial (SSM2-B and SSM2-C).

The Debrecen-Szepes site is a typical sporadic Makó settlement from the early phase of the EBA with only a few settlement features and one cremation grave. This grave belonged to a very young child where only a small amount of cremated bone was found. We analyzed a calcined bone (DES-C) from an urn, a small piece of hardwood charcoal (DES-O) from the pyre and a fragment of animal bone (DES-B) from the funerary finds (Dani et al. 2017). The exact identification of the animal bone dedicated to ${ }^{14} \mathrm{C}$ measurement was not possible due to the size but it probably originates from a herbivorous domesticated animal (ovicaprid or bovine).

At the Győr-Ménfőssanak, Széles-földek site (GYM, northwestern Hungary), nine cremated graves from the end of the EBA (Kisapostag culture or the earliest Transdanubian Encrusted Pottery), were found in two separated burial groups. The burial used for our project was the urn grave no. S.6250. We dated one fragment of human calcined bone (GYM-C) and a charred grain (GYM-O) from the content of the urn (Tóth et al. 2016).

The Bonyhád-Biogas Factory site is a cemetery in southwestern Hungary with 184 recently excavated graves, which was apparently used over a long period of time. The earliest inhumation burials were associated with the EBA Kisapostag or the earliest Transdanubian Encrusted Pottery culture, before both the burial rite and the material culture underwent a transformation during the early MBA, characterized by the introduction of cremation burial practice. The use of the cemetery lasted from the EBA until the end of the MBA. Burial no. 85, without grave goods, was an "in situ" (i.e. in the grave itself) cremation from which a cremated human bone (BOB-C) and a hardwood charcoal from the pyre (BOB-O) was analyzed. Some cremated samples from this location were selected to investigate the best fraction for dating. A full description of the archaeological setting is reported elsewhere (Hajdu et al. 2016).

The last instance is the Monostor-erdő site from Debrecen, which is another sporadic EBA Makó settlement with an urn grave of an adult woman (DEM-C). In this case, there was no associated material from the same grave, thus an unburned bone from a herbivore found in a nearby storage pit was used as organic sample (DEM-B) (Dani et al. 2017).

92 


\section{I Major et al.}

\section{Preparation of Cremated Bone Samples}

Before any pretreatment, all the cremated samples were visually inspected. Visual observation revealed that the samples varied from partially black charred bone with no burn cracks to completely white bone with clear indication of burn cracks. Some samples with visible charred layers and burn cracks were also included in our studies due to the limited amount of material and number of samples. Based on previous publications, this would suggest organic residues and these would not be ideal samples (Munro et al. 2007). Later the FTIR analyses revealed that the samples with charred layers did not show any residual organic material.

For most of the cremated samples, charred and calcined fractions of the bones were processed together, following the protocol suggested by Lanting et al. (2001). A flowchart of the procedure is shown in Figure 1. Briefly, after visual inspection and washing of the samples with ultrapure water, both the internal and external surface of the bone fragments were abraded to remove coarse soil-derived contamination. Then, 4-5 g of the cremated fragments was treated with $2 \times 50 \mathrm{~mL}$ of $0.25 \mathrm{M}$ sodium chlorite $\left(24 \mathrm{hr}, 20^{\circ} \mathrm{C}\right)$ in a centrifuge tube to remove organic residues. For more effective cleaning, the reagent liquid was replaced halfway through the process. In addition, after filling the tubes with clean solution and before decanting, the samples were

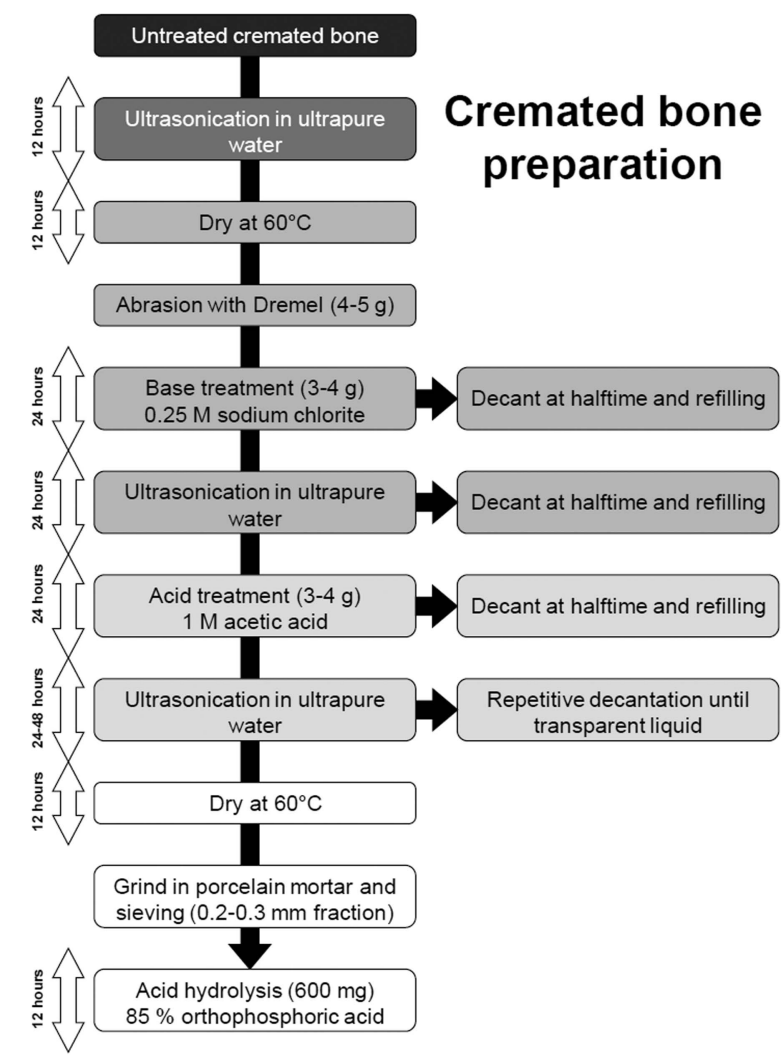

Figure 1 Flowchart of the cremated bone preparation. In case of hydrolysis, $600 \mathrm{mg}$ of cremated bone is placed in an extraction reactor with septum inlet designed at HEKAL, which is then evacuated through the valve to high vacuum. Subsequently, $5 \mathrm{~mL}$ of $85 \%$ orthophosphoric acid is added to the sample through the septum, using a needle and syringe. 
ultrasonicated for at least $15 \mathrm{~min}$. Subsequently, the samples were thoroughly washed in ultrapure water followed by treating the samples with $2 \times 50 \mathrm{~mL} 1 \mathrm{M}$ acetic acid $\left(24 \mathrm{hr}, 20^{\circ} \mathrm{C}\right)$ in the same manner as before to remove exogenous carbonates and less well-crystallized crystallites of apatite. Finally, all the samples were washed repetitively in ultrapure water again until a perfectly transparent liquid was observed and, after decantation, oven-dried at $60^{\circ} \mathrm{C}$ for an overnight. After drying, the pretreated samples were crushed in ceramic mortar and sieved. For dating, $600 \mathrm{mg}$ of the $0.2-0.3 \mathrm{~mm}$ fraction (and in the respective tests the $0.5-1 \mathrm{~mm}$ fraction as well) was treated with $85 \%$ orthophosphoric acid in a digestion reactor kept at $70^{\circ} \mathrm{C}$ overnight to release carbonate as $\mathrm{CO}_{2}$. The liberated $\mathrm{CO}_{2}$ was subsequently purified and trapped cryogenically using a customized vacuum line (Molnár et al. 2013). The carbon yield was calculated based on the pressure of the liberated $\mathrm{CO}_{2}$ gas. In addition, IAEA $\mathrm{C} 1$ standard material (fossil marble) powder was also treated as control sample for the $\mathrm{CO}_{2}$ extraction step, to determine if any modern carbon contamination was introduced during the extraction or graphitization procedure. However, the background originating from the physical and chemical treatment could not be determined in this way because such tiny amount of $\mathrm{C} 1$ and $\mathrm{C} 2$ standards were completely dissolved during the acetic acid step.

For FTIR measurements, the powder fraction of the bones remained after sieving was used without any further preparation. For the carbon stable isotope $\left(\delta^{13} \mathrm{C}\right)$ analyses, a small aliquot of $\mathrm{CO}_{2}$ gas liberated and purified in the vacuum line was used.

\section{Preparation of Associated Organic Samples}

Charcoal and charred grain samples were treated using an acid-base-acid (ABA) method following a standard protocol (Molnár et al. 2013). Briefly, the ABA protocol contains a sequence of $0.1 \mathrm{M} \mathrm{HCl}$, ultrapure water, $0.01 \mathrm{M} \mathrm{NaOH}$, ultrapure water steps and then a second $0.1 \mathrm{M} \mathrm{HCl}$ rinsing step (at room temperature) to remove ambient $\mathrm{CO}_{2}$ absorbed in the base step. After the final acid wash, the samples are washed to $\mathrm{pH} 4-5$ with ultrapure water and freeze-dried at least for $12 \mathrm{hr}$. The samples are then combusted stepwise on a vacuum line in a pure oxygen atmosphere. In the first step, samples are combusted in a quartz tube at the lower temperature of $400^{\circ} \mathrm{C}$ ("LT") and afterwards at a high temperature of $800^{\circ} \mathrm{C}$ ("HT"). The two resulting $\mathrm{CO}_{2}$ gas aliquots produce two separate targets (LT and HT carbon fraction) from each organic sample (McGeehin et al. 2001).

For pretreatment of intact bones, the extraction of collagen was performed at room temperature, using a semi-automated continuous flow system (Molnár et al. 2012, 2013). In this case, the reagents are selectively pumped through the glass reaction cells containing the ground bone samples (600 mg of the $0.5-1.0 \mathrm{~mm}$ fraction), with a sequence of $0.5 \mathrm{M} \mathrm{HCl}, 0.1 \mathrm{M} \mathrm{NaOH}$ and $0.5 \mathrm{M} \mathrm{HCl}$ solution again, rinsing with ultrapure water between each step. The cleaned bone samples together with $5 \mathrm{~mL}$ of $\mathrm{pH} 3$ solution are subsequently transferred into individual test tubes which are placed into a block heater at $75^{\circ} \mathrm{C}$ for $24 \mathrm{hr}$ to hydrolyze the gelatin. Finally, the dissolved fraction of each sample is filtered into glass vial using a $2 \mu \mathrm{m}$ glass fibre filter and freeze-dried for at least 2 days. The gelatin samples are then combusted using a modified sealedtube combustion method where the sample and $\mathrm{MnO}_{2}$ reagent are placed together in a borosilicate tube. After sealing, the tubes are placed in a muffle furnace at $550^{\circ} \mathrm{C}$ for at least $12 \mathrm{hr}$. The $\mathrm{CO}_{2}$ gas produced is then purified from any other by-product gases and quantified using a dedicated vacuum line (Janovics et al. 2015).

\section{Analytical Methods}

The infrared spectroscopic measurements of the cremated bones were carried out using a diamondhead Bruker Alpha-type Attenuated Total Reflectance Fourier Transform Infrared Spectrometer 
(ATR-FTIR) equipped with a Deuterated Lanthanum $\alpha$ Alanine doped TriGlycine Sulphate detector (DTGS, $4 \mathrm{~cm}^{-1}$ resolution). The analyzing depth was $\sim 1.66 \mu \mathrm{m}\left(\right.$ at $1000 \mathrm{~cm}^{-1}$ ). The data were collected and evaluated using the Opus 7.5 software package.

The carbon stable isotope analyses were performed by a Thermo Finnigan Delta Plus XP isotope ratio mass spectrometer in dual inlet mode. The results are expressed as delta values which is defined as follows: $\delta(\%)=\left(\mathrm{R}_{\text {sample }} / \mathrm{R}_{\text {reference }}-1\right) \times 1000$, where $\mathrm{R}_{\text {sample }}$ and $\mathrm{R}_{\text {reference }}$ is the ${ }^{13} \mathrm{C} /{ }^{12} \mathrm{C}$ ratio in the sample and in the international reference material, respectively. The $\delta^{13} \mathrm{C}$ results are reported relative to the VPDB standard and the overall precision of the measurements is $\pm 0.2 \%$.

For ${ }^{14} \mathrm{C}$ dating by AMS, graphite from the organic and cremated bone samples were prepared using a customized sealed tube graphitization method (Rinyu et al. 2013). The ${ }^{14} \mathrm{C}$ measurements reported below were performed with the EnvironMICADAS AMS instrument at HEKAL (Molnár et al. 2013b). The overall measurement uncertainty for modern samples is $<3.0 \%$, including normalization, background subtraction, and counting statistics. The conventional ${ }^{14} \mathrm{C}$ ages were evaluated by the "Bats" software (version 3.66; Wacker et al. 2010). Then, a blank correction was performed based on the mass and consensus ${ }^{14} \mathrm{C}$ values of the IAEA C1 standards. Finally, the conventional ${ }^{14} \mathrm{C}$ ages were converted to calendar ages using OxCal online (version 4.3.2; Bronk Ramsey 2009) and the IntCal13 calibration curve (Reimer et al. 2013).

\section{RESULTS AND DISCUSSION}

The ${ }^{14} \mathrm{C}$ dating experiments were divided into three subsets. As a preliminary test and the first subset, the $0.2-0.3 \mathrm{~mm}$ and $0.5-1 \mathrm{~mm}$ fractions of five cremated bones (from the BonyhádBiogas Factory location) were separated and processed in parallel and only their ${ }^{14} \mathrm{C}$ age were compared. In the second subset, three cremated fragments from the Szigetszentmiklós site were split into seven subsamples (SSM1-C/1-5 and SSM2-C/1-2) and processed in parallel, for both carbon yield and ${ }^{14} \mathrm{C}$ age. The results were subsequently compared to evaluate the reproducibility and the accuracy of the method (Table 2). For sample SSM1-C, two fragments were selected which were then subdivided into 2 and 3 pieces, respectively, resulting in 5 parallel subsamples. Since there was only one smaller fragment from sample SSM2-C, this cremated bone was just simply split into two (Figure 2). For sample SSM1-C (grave 128) we had no information regarding the expected ${ }^{14} \mathrm{C}$ age, but from the grave 107 , both a cremated and an intact bone (SSM2-C/1-2 and SSM2-B) were available hence we could make the comparison of the results.

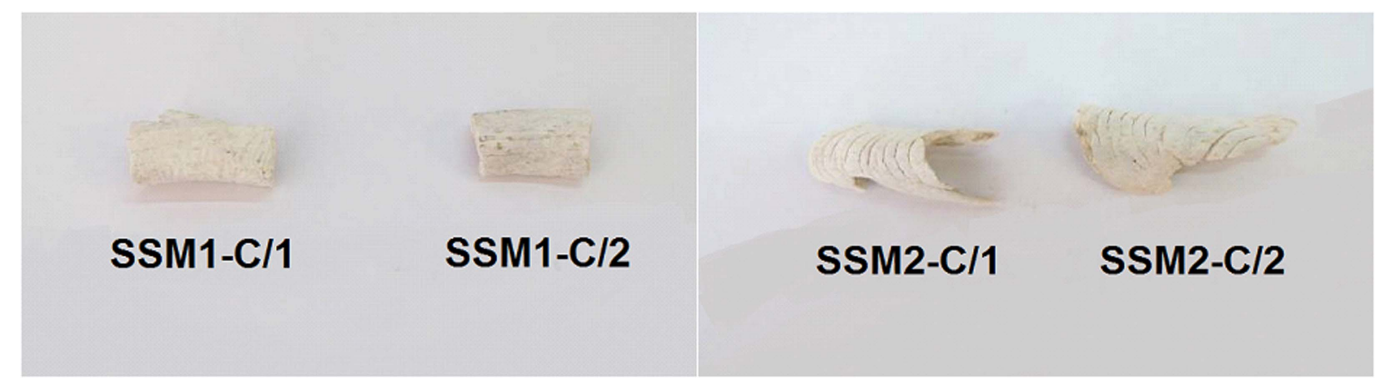

Figure 2 Fragments no. 1 and 2 of the SSM1 and SSM2 cremated bone samples used for the reproducibility tests. 
For the third series of measurements, the cremated bone samples of the remaining four sites were measured once and the respective results were compared to the ages of the associated organic material. Unfortunately, we only had the opportunity in one case to test the cremated bone (DES-C) against both charcoal (DES-O) and bone collagen (DES-B) materials from the same location. The two cremated fragments from the Debrecen, Monostor-erdô site (DEM-C/1 and 2) were tested against an intact bone (DEM-B), and the remaining two cremated samples (GYM-C and BOB-C) were against charcoal or charred grain (GYM-O and BOB-O, respectively).

\section{Results of FTIR Analyses}

Based on the FTIR analyses, we observed that the spectrum of each cremated sample clearly shows the characteristic carbonate peaks around the wavenumbers of 1400 and $870 \mathrm{~cm}^{-1}$. The most intense bands are around 1000 and $600 \mathrm{~cm}^{-1}$ that corresponds to the different phosphate vibrations. In each case, the broad peak typical for bone collagen and water between 3600 and $2600 \mathrm{~cm}^{-1}$ is missing due to the removal of water and degradation of organic material occurring at temperatures above $100^{\circ} \mathrm{C}$. Peaks originating from amide compounds generally appears in the spectrum between 1600 and $1700 \mathrm{~cm}^{-1}$ (Amide I) and between 1500 and $1600 \mathrm{~cm}^{-1}$ (Amide II) but these are not present if the bones are combusted at a temperature higher than $600^{\circ} \mathrm{C}$. Hence, we conclude that the incineration temperature of all the cremated samples was around or above $600^{\circ} \mathrm{C}$.

However, the FTIR spectrum of the cremated bones coded as SSM2-C/1-2, DES-C, and DEM-C/2 shows a small peak around $2012 \mathrm{~cm}^{-1}$, which is absent at the other samples (Figure 3). According to Hüls et al. (2010) this specific infrared frequency is related to cyanamide-apatite $\mathrm{Ca}_{9}\left(\mathrm{PO}_{4}\right)_{5}\left(\mathrm{HPO}_{4}\right)\left(\mathrm{HCN}_{2}\right)$, formed during heating of the apatite in an ammonia atmosphere that originates from the burning organic material. Cyanamide-apatite was also reported by Van Strydonck et al. (2010), who used modern bone material together with the attached body tissue for cremation experiments. However, Snoeck et al. (2014) has demonstrated that cyanamide in cremated bone cannot be satisfactorily explained by the presence of external fuel or flesh and skin in the burning environment, so the presence of this particular peak representing cyanamide-apatite in cremated samples is still unexplained.

\section{Results of Carbon Stable Isotopic Analyses}

For some cremated bone samples, we had the opportunity to measure the carbon stable isotopic ratio $\left(\delta^{13} \mathrm{C}_{\mathrm{VPDB}}\right)$ from $\mathrm{CO}_{2}$ gas produced in the acid digestion process. The $\delta^{13} \mathrm{C}$ values obtained for the samples DES-C, GYM-C, BOB-C, DEM-C1, DEM-C2, were $-22.6 \%$, $-21.8 \%$ o, $-20.3 \%$ o $-22.6 \%$, and $-22.0 \%$, respectively. Olsen et al. (2008) observed an increasing trend in the $\delta^{13} \mathrm{C}$ values of the bio-apatite fraction going from $-16 \%$ for charred samples to $-23 \%$ o for fully cremated bones. Our results fall closer to $-23 \%$, suggesting a well-calcined state of the analyzed cremated bones despite the greyish discoloration. When the external white color of the samples is also considered, this suggests full degradation of endogenous and any other contaminating organic material. However, some authors suggest that the $\delta^{13} \mathrm{C}$ values only reflect the origin of the carbon with which the bone apatite has exchanged, instead of reflecting the degree of cremation (Hüls et al. 2010; Van Strydonck et al. 2010; Snoeck et al. 2014). More negative $\delta^{13} \mathrm{C}$ values suggest a greater proportion of $\mathrm{CO}_{2}$ originating from the fuel $\left(\delta^{13} \mathrm{C}\right.$ of wood is below $-23 \%$ ), while less negative values highlight an intake of collagen carbon $\left(\delta^{13} \mathrm{C}\right.$ of collagen is around $-19 \% 0$ ). Considering the $\mathrm{C}_{3}$ plants (between $-23 \%$ and $-34 \%$ ) as fuel material of the pyre, we expect more negative $\delta^{13} \mathrm{C}$ signals in the cremated bones than in the case of $\mathrm{C}_{4}$ plants (between $-8 \%$ and $-16 \%$; Das et al. 2010), which were rarely used as fuel. 


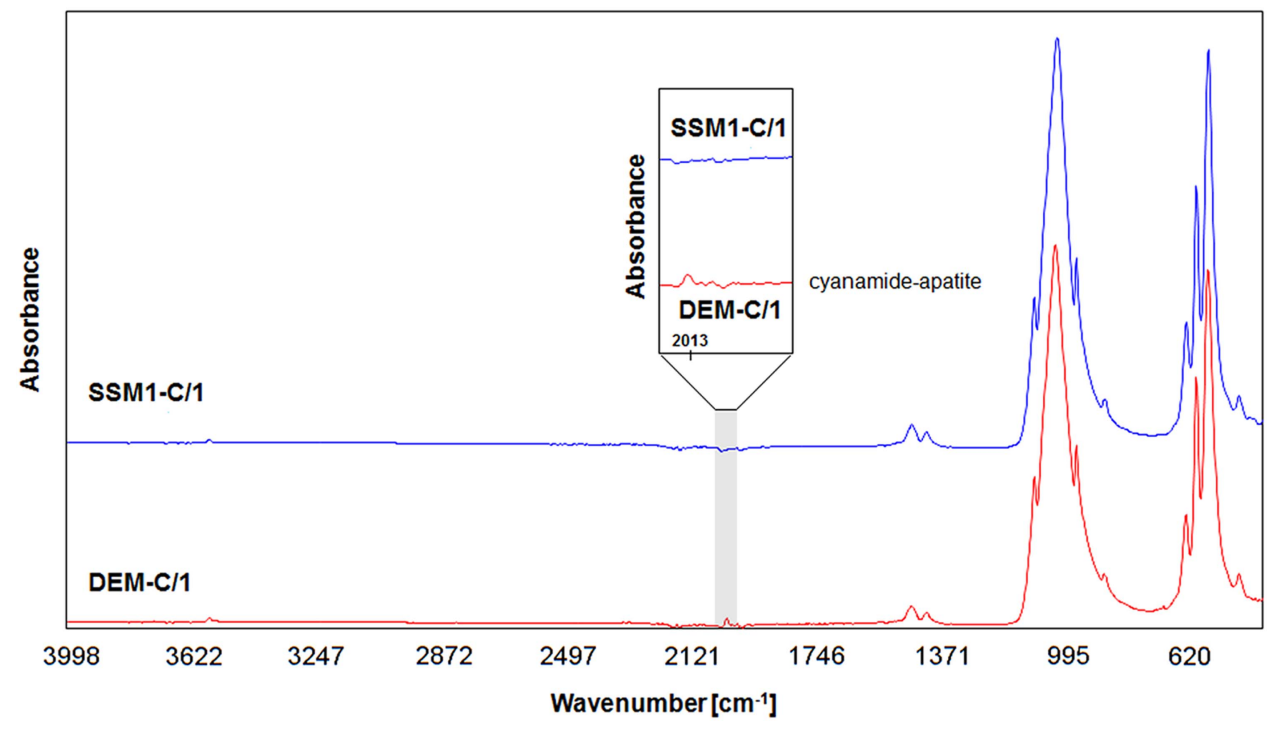

Figure 3 FTIR spectrum of the SSM-C/1 and DEM-C/1 cremated samples. For DEM-C/1, the peak of the cyanamide is visible while in the case of SSM1-C/1, this peak is missing.

\section{Results of Radiocarbon Measurements}

In the case of the first subset of test measurements, the $0.2-0.3 \mathrm{~mm}$ fraction gave systematically $30-120 \mathrm{yr}($ mean $=90 \mathrm{yr})$ older ${ }^{14} \mathrm{C}$ ages than the $0.5-1 \mathrm{~mm}$ fraction. The exact reason of this effect is still under investigation. Since the archaeological evidence supports the older ages and previous studies (Cherkinsky et al. 2009) also used the powder fraction of cremated bones after grinding, we only used the $0.2-0.3 \mathrm{~mm}$ fraction in the subsequent studies. In addition, thorough washing with ultrapure water at the end of chemical pretreatment also seems to be a critical step of the whole process. We found that the cloudy (whitish and not perfectly transparent) color of the liquid above the sample was an indicator of some less-crystallized crystal present, which could be more prone to contamination. Thus, ultrasonication and thorough washing of the samples is an important step in the chemical pretreatment that has to be emphasized.

Carbon yield and conventional ${ }^{14} \mathrm{C}$ age results of the reproducibility test samples (second subset) are summarized in Table 2. The carbon content of the cremated samples, calculated from the $\mathrm{CO}_{2}$ gas released by acid hydrolysis, ranges from 0.33 to $0.45 \%$. Lower values generally occur for samples that seem more completely burned and without visibly charred areas. In the course of our tests, we found no correlation between the carbon content and $\delta^{13} \mathrm{C}$ values. The measurement of the IAEA C1 (consensus value: $0.0000 \pm 0.0002 \mathrm{~F}^{14} \mathrm{C}$ ) standard samples did not indicate significant contamination $\left(\max .0 .008 \mathrm{~F}^{14} \mathrm{C}\right.$, mean $0.004 \pm 0.002 \mathrm{~F}^{14} \mathrm{C}$ ) originating from the $\mathrm{CO}_{2}$ extraction or graphitization processes, so we used the observed values for blank subtraction.

In the reproducibility test, the ${ }^{14} \mathrm{C}$ age of the parallel subsamples are in good agreement. Fragment no. 1 from sample SSM1-C (subsamples 1 and 2) gave ${ }^{14} \mathrm{C}$ ages of $3625 \pm 25$ and $3575 \pm 25 \mathrm{yr} \mathrm{BP}$ which agree within $1 \sigma$. Fragment no. 2 (subsamples 3, 4, and 5) originating from the same grave provided three dates of $3690 \pm 25,3595 \pm 25$ and $3615 \pm 25 \mathrm{yr}$ BP which are, excluding the first date, very similar and agree with the two dates of the previous fragment within $50 \mathrm{yr}$. Excluding the outlier (SSM1-C/3), the final average value of the four results is $3603 \mathrm{yr}$ BP with a standard 
Table 2 Carbon yield and blank corrected ${ }^{14} \mathrm{C}$ results for samples of the reproducibility tests from Szigetszentmiklós.

\begin{tabular}{|c|c|c|c|c|c|c|}
\hline Sample ID & Lab code & $\mathrm{C}(\%)$ & $\mathrm{F}^{14} \mathrm{C}$ & $\begin{array}{l}{ }^{14} \mathrm{C} \text { age } \\
\text { (yr BP) }\end{array}$ & Average \pm SD & Location \\
\hline SSM1-C/1 & DeA-9057 & 0.37 & $0.6368 \pm 0.0020$ & $3625 \pm 25$ & & Grave 128. \\
\hline SSM1-C/2 & DeA-9058 & 0.43 & $0.6408 \pm 0.0020$ & $3575 \pm 25$ & $3600 \pm 35$ & $\begin{array}{l}\text { Cremated bone } \\
\text { fragment no. } 1\end{array}$ \\
\hline $\mathrm{SSM} 1-\mathrm{C} / 3$ & DeA-9059 & 0.36 & $0.6317 \pm 0.0020$ & $3690 \pm 25$ & & Grave 128. \\
\hline SSM1-C/4 & DeA-9060 & 0.45 & $0.6392 \pm 0.0020$ & $3595 \pm 25$ & & Cremated bone \\
\hline SSM1-C/5 & DeA-9061 & 0.33 & $0.6376 \pm 0.0020$ & $3615 \pm 25$ & $3633 \pm 50$ & fragment no. 2 \\
\hline SSM2-C/1 & DeA-9202 & 0.41 & $0.6247 \pm 0.0023$ & $3780 \pm 30$ & & Grave 107 \\
\hline $\mathrm{SSM} 2-\mathrm{C} / 2$ & DeA-9062 & 0.40 & $0.6289 \pm 0.0020$ & $3725 \pm 25$ & $3753 \pm 39$ & $\begin{array}{l}\text { Cremated bone } \\
\text { (cr.grave) }\end{array}$ \\
\hline SSM2-B & DeA-9530 & 42.30 & $0.6200 \pm 0.0027$ & $3840 \pm 35$ & $3840 \pm 35$ & $\begin{array}{l}\text { Grave 107. Bone } \\
\text { c. (inh.gr.) }\end{array}$ \\
\hline
\end{tabular}

deviation of $22 \mathrm{yr}$. Including the outlier result, the final average value would shift to $3620 \mathrm{yr}$ BP and the standard deviation would be doubled. Unfortunately, no associated material was available in this case to independently confirm this ${ }^{14} \mathrm{C}$ date.

In the other case, a cremated fragment of the sample SSM2-C (subsamples 1 and 2) found at the same site but in another grave was used since its age was expected to be very close to the previous sample (SSM1-C). In the case of the two subsamples, the carbon yields were approximately the same, 0.41 and $0.40 \%$, respectively. The resulting ages of $3780 \pm 30$ and $3725 \pm 25 \mathrm{yr} \mathrm{BP}$ for the fragments are identical within $1 \sigma$, but the associated unburned bone (SSM2-B) gave a ${ }^{14} \mathrm{C}$ age of $3840 \pm 30 \mathrm{yr}$ BP. The average age value of the cremated samples is $3753 \mathrm{yr}$ BP with a standard deviation of $39 \mathrm{yr}$, which differs by $87 \mathrm{yr}$ from the age of the intact bone sample. It falls almost within the $2 \sigma$ uncertainty range, meaning the two ages cannot be distinguished at $95 \%$ confidence. From an archaeological perspective, it is conceivable that the cremation represents a slightly later burial, dug secondarily into the inhumation grave. The carbon yield and ${ }^{14} \mathrm{C}$ age results of cremated bones are in good agreement within $1 \sigma$ and the comparison with the associated bone material from inhumation also confirms the usability of the method. However, the standard deviation of the two cremated result, in the same way as the previous case, is almost $40 \mathrm{yr}$, suggesting that in case of any other cremated samples, it is worth doubling the uncertainty range of the mean age result. Finally, the discrepancy between the mean values of the cremated samples SSM1-C and SSM2-C is as much as $140 \mathrm{yr}$, which suggests that the two cremated samples may be of different age.

For the remaining case studies (third subset), the most comprehensive comparison could be performed on the samples originating from the Debrecen-Szepes site, as three different types of material were available (cremated bone, intact bone, and charcoal). The ${ }^{14} \mathrm{C}$ ages of the cremated bone sample and associated materials are shown in Table 3 . Based on the visual inspection, the external layer of the cremated bone was white while the interior between the calcined layers had a greyish appearance suggesting it was only charred but not completely calcined. However, the FTIR analyses did not show any indication of organic contamination. The cremated sample yielded a ${ }^{14} \mathrm{C}$ age of $3910 \pm 35 \mathrm{yr}$ BP which is slightly older but still very consistent with the ${ }^{14} \mathrm{C}$ ages of $3875 \pm 40$ and $3855 \pm 30 \mathrm{yr}$ BP measured on the bone collagen 
and hardwood charcoal samples, respectively. The excellent agreement of sample ages and the difference of $55 \mathrm{yr}$ also support the reliability of our procedure. Furthermore, the calibrated date obtained for the cremated bone (2500-2200 cal BC) sample fits well with the known absolute chronology of the Makó culture in the early phase of the EBA.

In the case of the Gyôr-Ménfőcsanak site, in addition to the cremated bone, some charred grains were found which allowed us to compare the dates. A single grain was combusted stepwise at a lower $\left(400^{\circ} \mathrm{C}\right)$ and a higher $\left(800^{\circ} \mathrm{C}\right)$ temperature then the $\mathrm{CO}_{2}$ aliquots were collected separately and ${ }^{14} \mathrm{C}$ dated. It is expected that carbon originating from organic contamination remaining on the surface is released at the lower temperature of $400^{\circ} \mathrm{C}$, while the endogenous carbon of the sample is liberated at the higher temperature of around $800^{\circ} \mathrm{C}$ (Wang et al. 2010; Újvári et al. 2016). The ${ }^{14} \mathrm{C}$ ages of the fractions obtained at the lower and higher temperatures were $3490 \pm 50$ and $3515 \pm 60 \mathrm{yr} \mathrm{BP}$, implying that this sample was not contaminated significantly. In contrast to charcoal, charred grain may represent a better material for determination of the exact historical period due its shorter growing period. The cremated bone yielded a date of $3450 \pm 30 \mathrm{yr} \mathrm{BP}$, which is in a good agreement with the date of the grain seed. The calibrated age of the seed (2020-1680 cal BC) matches with the expected archaeological age of the burial, while the date of the cremated bone (1880-1680 cal BC) seems slightly younger than the expected one.

At the Bonyhád-Biogas Factory site, a charcoal sample was excavated adjacent to a cremated bone. The high temperature date of the charcoal and the conventional date of the cremated bone sample are in a perfect agreement ( $3420 \pm 25$ and $3450 \pm 25 \mathrm{yr}$ BP, respectively). These two results are slightly younger (range of 1880-1640 cal BC) than expected. The results can be accepted as a later phase of the MBA in the Carpathian Basin, as discussed by Dani et al. (2017). Nevertheless, charcoal commonly is not a preferred material for accurate comparisons since the old wood effect could cause a significant discrepancy between the dates obtained to paired charcoal and bioapatite samples. Lanting et al. (2001) also observed large age differences in some cases, using charcoal as context dated reference material, thus such comparisons have to be treated with caution.

Table 3 Carbon yield and blank corrected ${ }^{14} \mathrm{C}$ results for the tested archaeological organic and cremated samples.

\begin{tabular}{|c|c|c|c|c|c|c|}
\hline Sample ID & Material type & Lab code & $\mathrm{C}(\%)$ & $\mathrm{F}^{14} \mathrm{C}$ & $\begin{array}{l}{ }^{14} \mathrm{C} \text { age } \\
\text { (yr BP) }\end{array}$ & Location \\
\hline DES-O & Charcoal & DeA-9021 & 34.30 & $0.6173 \pm 0.0031$ & $3875 \pm 40$ & \multirow{3}{*}{$\begin{array}{l}\text { Debrecen-Szepes } \\
\text { Grave 238/319 }\end{array}$} \\
\hline DES-B & Bone collagen & DeA-9189 & 43.40 & $0.6188 \pm 0.0023$ & $3855 \pm 30$ & \\
\hline DES-C & Crem. bone & DeA-9428 & 0.47 & $0.6146 \pm 0.0027$ & $3910 \pm 35$ & \\
\hline GYM-O & $\begin{array}{l}\text { Charred grain } \\
\text { (LT) }\end{array}$ & DeA-9038 & 26.00 & $0.6476 \pm 0.0040$ & $3490 \pm 50$ & \multirow[t]{3}{*}{$\begin{array}{l}\text { Győr-Ménfő́csanak } \\
\text { Grave 6250.str. }\end{array}$} \\
\hline GYM-O & $\begin{array}{l}\text { Charred grain } \\
\text { (HT) }\end{array}$ & DeA-9039 & 19.40 & $0.6456 \pm 0.0048$ & $3515 \pm 60$ & \\
\hline GYM-C & Crem. bone & DeA-9429 & 0.32 & $0.6508 \pm 0.0024$ & $3450 \pm 30$ & \\
\hline BOB-O & Charcoal & DeA-5151 & 59.40 & $0.6533 \pm 0.0020$ & $3420 \pm 25$ & \multirow{2}{*}{$\begin{array}{l}\text { Bonyhád-Biogas F., } \\
\text { Grave } 85 \text {. }\end{array}$} \\
\hline BOB-C & Crem. bone & DeA-5921 & 0.50 & $0.6508 \pm 0.0020$ & $3450 \pm 25$ & \\
\hline DEM-B & Bone collagen & DeA-9190 & 38.90 & $0.6177 \pm 0.0023$ & $3870 \pm 30$ & \multirow{3}{*}{$\begin{array}{l}\text { Debrecen, } \\
\text { Monostor-erdő Pit } \\
\text { 563/1075 } \\
\text { Grave 619/1145 }\end{array}$} \\
\hline DEM-C/1 & Crem. bone & DeA-9424 & 0.56 & $0.6289 \pm 0.0023$ & $3725 \pm 30$ & \\
\hline DEM-C/2 & Crem. bone & DeA-9425 & 0.24 & $0.6051 \pm 0.0026$ & $4035 \pm 35$ & \\
\hline
\end{tabular}


From the Debrecen, Monostor-erdô site, an intact bone sample was used as the organic pair of the cremated bones. The ${ }^{14} \mathrm{C}$ results from the unburned and two calcined bone fragments are presented in Table 3. In this case study, two completely calcined (white) bone fragments (DEM$\mathrm{C} / 1$ and DEM-C/2) found in the same urn were selected to be used for comparison. A significant difference in the carbon yield ( 0.56 and $0.24 \mathrm{wt} \%$, respectively) was observed and while the characteristic cyanamide peak is present in the FTIR spectrum of the first sample, it is absent from the other fragment. We expected the ${ }^{14} \mathrm{C}$ date of the intact bone to be similar to that of the cremated bones but the measurements did not confirm this assumption. The age of the unburned bone was $3870 \pm 30 \mathrm{yr} \mathrm{BP}$, while the cremated ones were $3725 \pm 30$ and $4035 \pm 35 \mathrm{yr}$ $\mathrm{BP}$, respectively. The age of the organic material differs nearly $150 \mathrm{yr}$ from the ages of both cremated samples but interestingly the cremated bones gave ${ }^{14} \mathrm{C}$ ages different by almost $300 \mathrm{yr}$. The cremated bones and the associated unburned bone were found at the same site but not in the same archaeological feature, which may explain the large age discrepancy. However, the difference between the two cremated fragments is a more significant issue. We repeated the chemical pretreatment and measurement with both cremated fragments but we confirmed the same results, so these differences are not due to sample processing. Past experimental results have indicated that the contribution of fuel carbon to structural carbonate of cremated bone can be significant and can easily change the actual age of the sample, hence caution should be used in accepting the relatively older ${ }^{14} \mathrm{C}$ results of calcined bone (Zazzo et al 2011). However, at this site, the archaeological context supports the older age (2840-2470 cal BC) rather than the younger one (2210-2030 cal BC). The higher carbon content and the cyanamide peak observed for the first fragment also suggest that these two fragments has a different origin, in spite of deriving from the same urn. Further study of this grave site is needed to find the exact reason of the discrepancy and usage of other independent analysis/techniques proving more analytical results is highly recommended.

\section{SUMMARY}

In this ${ }^{14} \mathrm{C}$ dating study, different types of archaeological samples were analyzed to establish the preparation of cremated bone samples for AMS measurements at HEKAL and evaluate the reproducibility and accuracy of our pretreatment protocol. The FTIR and $\delta^{13} \mathrm{C}$ analyses confirmed that no significant organic material remained in the selected samples and each bone was properly cremated. Using the adopted chemical pretreatment protocol, the $0.2-0.3 \mathrm{~mm}$ fraction of cremated bones provided systematically older ages relative to the $0.5-1 \mathrm{~mm}$ fraction and the whole preparation process did not influence significantly the reproducibility of the bioapatite samples. In most of the case studies, the dates of the cremated samples were in a good agreement with results of the associated organic materials. Good agreement was found in a single case comparing short-lived charred grain and cremated bone. However, in one case (at Debrecen, Monostor-erdő site), a large age discrepancy $(\sim 300 \mathrm{yr})$ of the two cremated fragments originating from the same urn shows that sometimes other effects such as isotopic exchange could modify the ${ }^{14} \mathrm{C}$ age. In such cases, it is always important to use other independent supporting analysis/techniques to evaluate the correct ${ }^{14} \mathrm{C}$ ages from these materials.

\section{ACKNOWLEDGMENTS}

The research was supported by the European Union and the State of Hungary, co-financed by the European Regional Development Fund in the project of GINOP-2.3.2-15-201600009 'ICER'. The paper was supported by the Momentum Mobility research project of the Hungarian Academy of Sciences. The authors would like to thank Anita Molnár and Renáta Gönczi for their careful sample handling and preparation. 


\section{REFERENCES}

Bronk Ramsey C. 2009. Bayesian analysis of radiocarbon dates. Radiocarbon 51(1):337-60.

Cherkinsky A. 2009. Can we get a good radiocarbon age from "bad bone"? Determining the reliability of radiocarbon age from bioapatite. Radiocarbon 51(2):647-55.

Csongor É, Bognár-Kurtizán I, Szabó I, Hertelendi E. 1983. Radiocarbon dating of Holocene bone samples in Hungary. Chemical and Mathematical Techniques Applied to Archaeology 8:385.

Dani J, Köhler K, Kulcsár G, Major I, Melis E, Patay R, Szabó G, Hajdu T, Hubay K, Futó I, Huszánk R, Molnár M, Kiss V. 2017. Case studies for the dating of Bronze Age cremation burials from Hungary. In: Nona Palincas, editor. Proceedings of the Fifth Balkan Symposium of Archaeometry.

Das O, Wang Y, Hsieh YP. 2010. Chemical and carbon isotopic characteristics of ash and smoke derived from burning of $\mathrm{C} 3$ and $\mathrm{C} 4$ grasses. Organic Geochemistry 41:263-9.

Hajdu T, György-Toronyi A, Pap I, Rosendahl W, Szabó G. 2016. The chronology and meaning of the Transdanubian encrusted pottery decoration. Prähistorische Zeitschrift 91(2):353-68.

Hassan AA, Termine JD, Haynes CV. 1977. Mineralogical studies on bone apatite and their implications for radiocarbon dating. Radiocarbon 19(3):364-74.

Hüls CM, Erlenkeuser H, Nadeau M-J, Grootes PM, Andersen N. 2010. Experimental study on the origin of cremated bone apatite carbon. Radiocarbon 52(2):587-99.

Janovics R. 2015. Development of radiocarbon-based measuring methods and their application for nuclear environmental monitoring [PhD thesis]. Debrecen, Hungary: University of Debrecen Press.

Lanting JN, Aerts-Bijma AT, van der Plicht J. 2001. Dating of cremated bones. Radiocarbon 43(2A): 249-54.

Lee-Thorp JA, van der Merwe NJ. 1991. Aspects of the chemistry of modern and fossil biological apatites. Journal of Archaeological Science 18(3): 343-54.

Longin R. 1971. New method of collagen extraction for radiocarbon dating. Nature 230(5291):241-2.

Mays S. 1998. The Archaeology of Human Bones. London: Routledge.

McGeehin J, Burr GS, Jull AJT, Reines D, Gosse J, Davis PT, Muhs D, Southon J. 2001. Steppedcombustion ${ }^{14} \mathrm{C}$ dating of sediment: A comparison with established techniques. Radiocarbon 43 (2A):255-61.

Molnár M, Rinyu L, Janovics R, Major I, Veres M. 2012. Introduction of the new AMS C-14 laboratory in Debrecen. Archeometriai Múhely 9(3): 147-60.

Molnár M, Janovics R, Major I, Orsovszki J, Gönczi R, Veres M, Leonard AG, Castle SM, Lange TE,
Wacker L, Hajdas I, Jull AJT. 2013. Status report of the new AMS ${ }^{14} \mathrm{C}$ sample preparation lab of the Hertelendi Laboratory of the Environmental Studies (Debrecen, Hungary). Radiocarbon 55(2-3):665-76.

Molnár M, Rinyu L, Veres M, Seiler M, Wacker L, Synal H-A. 2013b. EnvironMICADAS: a mini ${ }^{14} \mathrm{C}$ AMS with enhanced gas ion source interface in the Hertelendi Laboratory of Environmental Studies (HEKAL), Hungary. Radiocarbon 55(2-3):338-44.

Munro LE, Longstaffe J, White CD. 2007. Burning and boiling of modern deer bone: Effects on crystallinity and oxygen isotope composition of bioapatite phosphate. Palaeogeography, Palaeoclimatology, Palaeoecology 249:90-102.

Naysmith P, Scott EM, Cook GT, Heinemeier J, van der Plicht J, Van Strydonck M, Bronk Ramsey C, Grootes PM, Freeman SPHT. 2007. A cremated bone intercomparison study. Radiocarbon 49(2): 403-8.

Olsen J, Heinemeier J, Bennike P, Krause C, Hornstrup KM, Thrane H. 2008. Characterisation and blind testing of radiocarbon dating of cremated bone. Journal of Archaeological Science 35:791-800.

Patay R. 2013. Bell Beaker cemetery and settlement at Szigetszentmiklós: first results. In: Transitions to the Bronze Age. Interregional Interaction and SocioCultural Change in the Third Millennium BC Carpathian Basin and Neighbouring Regions. p 287-317.

Quarta G, Tiberi I, Rossi M, Aprile G, Braione E, D'Elia M, Ingravallo E, Calcagnile L. 2014. The Cooper Age Mound Necropolis in Salve, Lecce, Italy: radiocarbon dating results on charcoals, bones. cremated bones and pottery. Radiocarbon 56(3):949-57.

Reimer PJ, Bard E, Bayliss A, Warren Beck J, Blackwell PG, Bronk Ramsey C, Grootes PM, Guilderson TP, Haflidason H, Hajdas I, Hatte C, Heaton TJ, Hoffmann DL, Hogg AG, Hughen KA, Kaiser KF, Kromer B, Manning SW, Niu M, Reimer RW, Richards DA, Scott EM, Southon JR, Staff RA, Turney CSM, van der Plicht J. 2013. IntCal13 and Marine13 radiocarbon age calibration curves 0 50,000 years cal BP. Radiocarbon 55(4):1869-87.

Richards MP, Hedges REM. 1999. Stable isotope evidence for similarities in the types of marine foods used by late mesolithic humans at sites along the Atlantic coast of Europe. Journal of Archaeological Science 26:717-22.

Rinyu L, Molnár M, Major I, Nagy T, Veres M, Kimák Á, Wacker L, Synal H-A. 2013. Optimization of sealed tube graphitization method for environmental ${ }^{14} \mathrm{C}$ studies using MICADAS. Nuclear Instruments and Methods in Physics Research B 294(1):270-5.

Snoeck C, Brock F, Schulting RJ. 2014. Carbon exchanges between bone apatite and fuels during cremation: impact on radiocarbon dates. Radiocarbon 56(2):591-602.

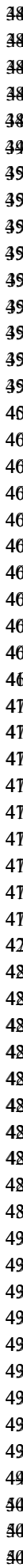


Starkovich BM, Hodgins GWL, Voyatzis ME, Romano DG. 2013. Dating gods: radiocarbon dates from the sanctuary of Zeus on Mt. Lykaion (Arcadia, Greece). Radiocarbon 55(2):501-13.

Surovell TA. 2000. Radiocarbon dating of bone apatite by step heating. Geoarchaeology 15:591-608.

Taylor RE, Aitken MJ. 1997. Chronometric dating in archaeology. Advances in Archaeological and Museum Science.

Tóth G, Melis E, Ilon G. 2016. The anthropological and corresponding archaeological results of the Bronze Age material from the Ménfócsanak excavation (2009-2011). In: Csécs T, Takács M, editors. Beatus homo qui invenit sapientiam. Ünnepi kötet Tomka Péter 75. Születésnapjára. Győr. p 737-55.

Újvári G, Molnár M, Barna-Páll G. 2016. Charcoal and mollusc shell ${ }^{14} \mathrm{C}$-dating of the Dunaszekcső loess record, Hungary. Quaternary Geochronology 35:43-53.

Van Strydonck M, Boudin M, Hoefkens M, De Mulder G. 2005 . ${ }^{14} \mathrm{C}$ dating of cremated bones, why does it work? Lunula 13:3-10.
Van Strydonck M, Boudin M, De Mulder G. 2009.

${ }^{14} \mathrm{C}$ dating of cremated bones: the issue of sample contamination. Radiocarbon 51(2):553-68.

Van Strydonck M, Boudin M, De Mulder G. 2010. The carbon origin of structural carbonate in bone apatite of cremated bones. Radiocarbon 52(2): 578-86.

Vaughan JM. 1970. The Physiology of Bone. Oxford: Clarendon Press.

Wacker L, Christl M, Synal H-A. 2010. Bats: A new tool for AMS data reduction. Nuclear Instruments and Methods in Physics Research B 268:976-9.

Wang H, Ambrose SH, Hedman KM, Emerson TE. 2010. AMS ${ }^{14} \mathrm{C}$ dating of human bones using sequential pyrolysis and combustion of collagen. Radiocarbon 52(1):157-63.

Zazzo A, Saliège JF, Person A, Boucher H. 2009. Radiocarbon dating of cremated bones, where does the carbon come from? Radiocarbon 51(2): 601-11.

Zazzo A, Saliège JF. 2011. Radiocarbon dating of biological apatites: a review. Palaeogeography, Palaeoclimatology, Palaeoecology 310:52-61. 